\title{
Time budget patterns and complementary use of a Mediterranean wetland (Tonga, North-east Algeria) by migrant and resident waterbirds
}

\author{
Elafri Ali ${ }^{*}$, Halassi Ismahan ${ }^{1}$, Houhamdi Moussa ${ }^{2}$
}

\begin{abstract}
Riassunto - Andamento temporale e uso complementare di una zona umida mediterranea (Tonga, Nord-est Algeria) da parte degli uccelli acquatici migranti e residenti.

Abbiamo effettuato una descrizione quantitativa sull'uso di una zona umida mediterranea (Tonga, nord-est dell'Algeria) da parte di 22 specie di uccelli acquatici (11 residenti e 11 migratori paleartici) durante il periodo di fine-estate inizio-inverno, analizzando anche la loro gestione del tempo diurno e le relative principali caratteristiche del paesaggio. Le analisi delle analogie nella gestione del tempo da parte degli uccelli (analisi del clustering gerarchico) ha mostrato 4 gruppi di specie associati a 4 attività principali: nutrimento principalmente nelle ore diurne (11 specie), dormire (6), nuotare (3) e riposare (2). Le specie residenti (aironi e rallidi) hanno mostrato un tempo di nutrimento maggiore rispetto alle specie migratorie (anatre tuffatrici, gabbiani e cormorani). Dal periodo di fine-estate a quello di inizio-inverno le abitudini dei migratori cambiano, mentre i residenti si comportano uniformemente durante le ore diurne e durante il corso della stagione. L'utilizzo di questa zona umida naturale in maniera complementare da parte di una gran numero di uccelli acquatici (residenti e migratori) è favorita principalmente dalla presenza di numerosi tipi di habitat. Abbiamo constatato che sono 3 le principali unità ecologiche più utilizzate come habitat di foraggiamento tra podicipedidae Bonaparte, rallidi, anatre, gabbiani ed aironi: corpo idrico aperto, piane tidali e prati allagati. Al contrario, vegetazione a foglie galleggianti ed emergente alta erano le categorie di habitat più comuni usate nelle attività di riposo, soprattutto da cormorani ed aironi. I dati raccolti sui requisiti di comportamento di questi uccelli acquatici possono essere utilizzati per la conservazione e la corretta gestione di questa e di altre zone umide costiere mediterranee.
\end{abstract}

Parole chiave: comportamento diurno, microhabitat, metodo di coordinamento, periodo stagionale, uccelli acquatici.

Abstract - We carried out a quantitative description of the use of a Mediterranean wetland (Tonga, North-east Algeria) by 22 waterbirds

${ }^{1}$ Department of Biology and Animals Physiology, Faculty of Natural Science, Ferhat Abbas Setif-1 University, El-Bez, Sétif, 19000, Algeria.

E-mail: alvierose@yahoo.fr

${ }^{2}$ Laboratory: LBEE Biology, SNV-STU Faculty, Biology, Water and Environment Laboratory, Natural Sciences Department, 8 Mai 1945 University of Guelma, Algeria.

E-mail: houhamdimoussa@yahoo.fr

*Corresponding author: a.elafri@centre-univ-mila.dz

(C) 2016 Elafri Ali, Halassi Ismahan, Houhamdi Moussa

Received: 17 January 2016

Accepted for publication: 7 July 2016 species (11 residents and 11 Palaearctic migrants) during late summerwintering period, also analyzing their species-specific diurnal time budgets and the main related features of the landscape. The analyses of similarity in time budgets across birds (Hierarchal Cluster Analysis) showed four clusters of species associated with four major activities: day time mostly feeding (11 species), sleeping (6), swimming (3) and resting (2). Residents (Herons and Rails) showed a higher feeding time when compared to migrants (diving ducks, Gulls and Cormorants). From late summer to winter the time budget activity change in migrants; in contrast residents behave uniformly among daytime and at the course of the season. The use of this natural wetland in a complementary way by a high number of waterbirds (residents and migrants), is principally promoted by the existing of numerous habitat types. We found that 3 main ecological units, open water body, mudflats, and flooded meadows were the most utilized as foraging habitats among grebes, rails, ducks, gulls, and herons. In contrast, floating-leafed vegetation, and tall emergent vegetation were the commonest habitat categories used in resting activities especially by cormorants and herons. Data on behaviour requirements of these waterbirds can be used for conservation and correct management of this and other Mediterranean coastal wetlands.

Key words: Diurnal behavior, microhabitats, ordination method, seasonal period, waterbirds.

\section{INTRODUCTION}

Mediterranean wetlands are important late summer stopover and wintering sites for large flocks of waterbirds and are located along migratory flyways (PalearcticAfrican migration) of many Palearctic and sub-Saharan species (Samraoui, 2008; Liordos, 2010). Every year, migratory birds spend two-thirds of their time in wintering and stopover sites. Many authors (Hoffmann et al., 1996; Liordos, 2010; Samraoui et al., 2011; Scarton et al., 2013) pointed out the key aspects of Mediterranean wetlands conservation and management to preserve these species. The value of a particular area as wintering refuge mainly depends on relative availability of suitable species-specific habitat types (Kloskowski, 2009; Rajpar, 2011). Mediterranean wetlands usually have a varying spatial configuration, at finer scale, they are characterized by a wide range of habitat features mainly influenced by water flows and vegetation physiognomy (Liordos, 2010). Therefore, wetland landscape units include: Flooded meadows, flooded forests, Mudflats, interspersed submerged and emergent vegetation and also open water body (Shine \& De Klemm, 1999). Species select often the available resources and the microhabitats in different ways throughout the wetlands, depending on their behaviour or spa- 
tial location for feeding (Paracuellos, 2006). Hence, behavioral responses are the first line of defense to selective environmental factors.

Studies on activity time budget of birds in their suitable habitats have been recognized as an important tool for understanding habitat use and niche separation, and consequently it is an invaluable aid for managing waterfowl communities and habitats (Hepworth \& Hamilton, 2001). For North-African waterbirds, activity patterns during non-reproductive periods have been quantified only for a few species, especially the endangered ones such as Marbled Duck Marmaronetta angustirostris, Ferruginous Duck Aythya nyroca and White-headed Duck Oxyura leucocephala (Green et al., 2000; Houhamdi \& Samraoui, 2001; Aissaoui et al., 2009; Meziane et al., 2014). Almost all studies considered single species or small communities and there have been no studies of activity patterns in large, multi-species assemblages.

Located in northeastern Algeria, Lake Tonga stands as one of the most distinctive natural reserve in the southern Mediterranean Sea. Almost $80 \%$ of its area is covered by rush beds and reed beds hosting 309 plant species (Boumezbeur, 1993). Among birds, this area hosts more than 25,000 wintering birds (52 waterbird species identified by Elafri et al., 2016). However, although the ornithological significance of this Ramsar site has been largely documented (Bakaria et al., 2002; Samraoui et al., 2008; Aissaoui et al., 2009; Nedjah et al., 2010; Lazli et al., 2012; Chettibi et al., 2013; see also Samraoui et al., 2013; Rouibi et al., 2013), an analysis of activity time budgets and behavioral information on the guild of wintering waterbirds are currently lacking.

This paper describes the activity rhythms (time allocation during intervals throughout the daylight hours) of an assemblage of selected wintering waterbirds. We refer to the term "assemblage", as a taxonomically related assortment of species seasonally occurring in the study area (Magurran, 2004). We estimated the time budget for a subset of 22 species, including tow distinctive assemblages, the Palearctic immigrant which Lake Tonga is the main wintering habitat and resident species during a pluriseasonal period (late summer-late winter). To our knowledge this is the first study conducted on this topic in a wet area of the North African coast.

\section{MATERIALS AND METHODS}

\section{Study area}

Lake Tonga $\left(36^{\circ} 51^{\prime} \mathrm{N}, 8^{\circ} 30^{\prime} \mathrm{E}\right)$ is a shallow freshwater marsh of 2700 ha situated in the extreme north-east of Algeria near the Algerian-Tunisian border at $3 \mathrm{Km}$ of the Mediterranean Sea and flows into it through an artificial canal (Fig. 1). Almost $80 \%$ of its area is covered by helophytes and hydrophytes dominated by Scirpus lacustris, Typha angustifolia, Nymphaea alba, Salix atrocinerea and Phragmites australis. It is designated as a Ramsar site since 1983 and is part of the El Kala National Park (PNEK) [Wilaya of El-Taref (Lazli et al., 2011)].The PNEK is a Man and Biosphere Reserve, part of an extensive wetland complex spread across northeast Algeria and housing a wide range of Important Bird Areas (IBA) and Ramsar sites (Samraoui \& Samraoui, 2008). The climate in the region is typically Mediterranean, characterized by warm to hot, dry summers and mild to cool, wet winters (Boumezbeur, 1993).

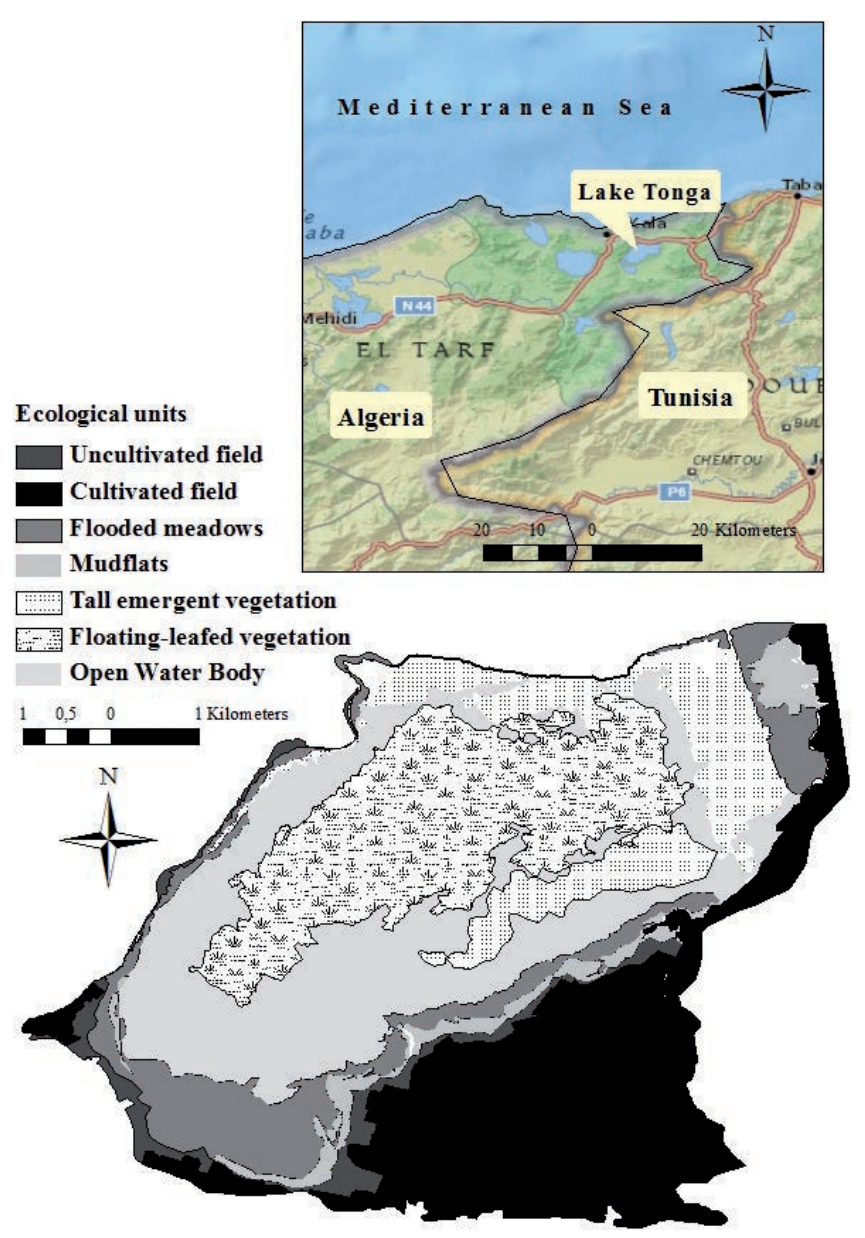

Fig. 1 - Map of the study area with an ortophotograph of the area. Ecological units are described in Material and Methods.

\section{Bird survey and behavioral observations}

Data was directly gathered from our observation through a representative visual point that were opportunistically chosen because of their relative accessibility and unhindered view, using a 20-40×60 telescope (Konus Spotting Scope).

Bird activities have been recorded according to the Instantaneous or Scan Sampling method. When using this method, the behaviour of all individuals in a group of animals are recorded at predetermined time intervals during the daytime hours (for more details, see Altman, 1974).

Twelve visits were made and $108 \mathrm{~h}$ of total research effort of the diurnal time budgets were conducted at Tonga Lake from late summer (September 2014) to winter (February 2015). Observations were undertaken hourly during daylight hours in two periods from sunrise to sunset, i.e. "morning" (from 7:00-12:00) and "afternoon" (from 13:00-17:00) at approximately bimonthly intervals. 
Sixty hours of observations were gathered in the morning and 48 observations hours were made in the afternoon. Further, according to the migration of the waterbirds in this area (arrival and departure of birds), the study period was divided into two phenological periods: i) late summer-autumn (September to November) and ii) winter (December to February).

To evaluate whether waterbirds change their daytime behaviour among the study periods, we surveyed a set of behaviours that were very easily identified as feeding, sleeping, swimming, resting (with comfort behaviour), flying, escaping (alert or vigilance), courtship (displays) and agonistic or antagonistic (aggressive behaviour; see Thompson \& Baldassarre, 1991; Clark et al., 1994).

\section{Habitat use}

Based on landscape elements observed from aerial photograph in winter and with the help of field observations, seven ecological units or substrates were categorized (Tab. 1 and Fig. 1).

Habitat use for each group of species was estimated using the following expression:

$$
n / N \times 100
$$

where $n$ is the number of individuals of a particular species group in a particular habitat and $N$ is the total number of individuals of the same group in the seven habitat types.

\section{Data analyses}

Activity time budgets were calculated by dividing number of instantaneous samples for each activity by total number of samples (Clark et al., 1994), and the proportion of time devoted to a given activity by each species and in each period was estimated from the proportion of individuals engaged in that activity (Fasola \& Canova, 1993). Firstly, a hierarchical cluster analysis grouped birds according to the percentage of their daytime allocated for different behaviours into the most similar clusters.
This cluster analysis was tested numerous times in order to achieve the "best" clustering (paired group UPGMA method to aggregate data and the Bray-Curtis method to calculate distances). Then, to look at differences in activity budget across waterbirds species (migrants and residents) at different times of day and through the wintering season we performed the $\chi 2$ goodness of fit test because all behaviours values in percentage inside each species did not fit the normal distribution (we used KolmogorovSmirnov Test to check whether the data was normally distributed), also neither Yates' correction of the data nor Bonferroni p-values correction have been performed. Statistical tests have been performed using Excel Stat. 2014 and Statistica.10. Alpha was set at 0.05 level.

\section{RESULTS}

\section{Activity budget}

Overall, 22 waterbird species, 11 residents (breeding in Lake Tonga) and 11 Palearctic immigrants (breeding in the Palaearctic and spending the winter in Lake Tonga) with different feeding ecology were sampled.

Feeding, resting, sleeping and swimming were the major diurnal activities observed among the studied birds during winter in Tonga Lake (Fig. 2). These four behaviours were the main driver of bird species clustering in the hierarchical cluster analysis (Fig. 3). According to this similarity analysis four groups of species were revealed. The first, more diversified, is formed by 11 species with a gradient of increasing feeding per cent ranging from 42 to $98 \%$ of the time observation (Figs. 2 and 3). In the dendrogram, these species were Eurasian Coot Fulica atra, Gadwall Anas strepera, Glossy Ibis Plegadis falcinellus, Little Egret Egretta garzetta, Cattle Egret Bubulcus ibis, Grey Heron Ardea cinerea, Purple Swamphen Porphyrio porphyrio, Common Moorhen Gallinula chloropus, Northern Shoveler Anas clypeata, Northern Lapwing Vanellus vanellus and Eurasian Wigeon Anas penelope.

Tab. 1 - Landscapes elements of the seven blocks.

\begin{tabular}{|c|c|}
\hline Habitat & Description \\
\hline Cultivated field (agricultural field) & $\begin{array}{l}\text { Land planted with an agricultural crop (did not distinguish between the types of } \\
\text { crops planted) }\end{array}$ \\
\hline Uncultivated field (grassy field) & Open land vegetated with grasses and forbs, never flooded. \\
\hline Flooded meadows & $\begin{array}{l}\text { Open land vegetated with grasses and forbs, periodically flooded in November- } \\
\text { June period }\end{array}$ \\
\hline Mudflats & Any exposed wet ground between the water and dry land, never vegetated. \\
\hline Tall emergent vegetation & $\begin{array}{l}\text { Corresponding to patches at macrophytes }>50 \mathrm{~cm} \text { (common club-rush and reed } \\
\text { bed) }\end{array}$ \\
\hline Floating-leafed vegetation & Corresponding to the Nymphaeid area \\
\hline Open water body & Larger and open area dominated by submerged vegetation \\
\hline
\end{tabular}




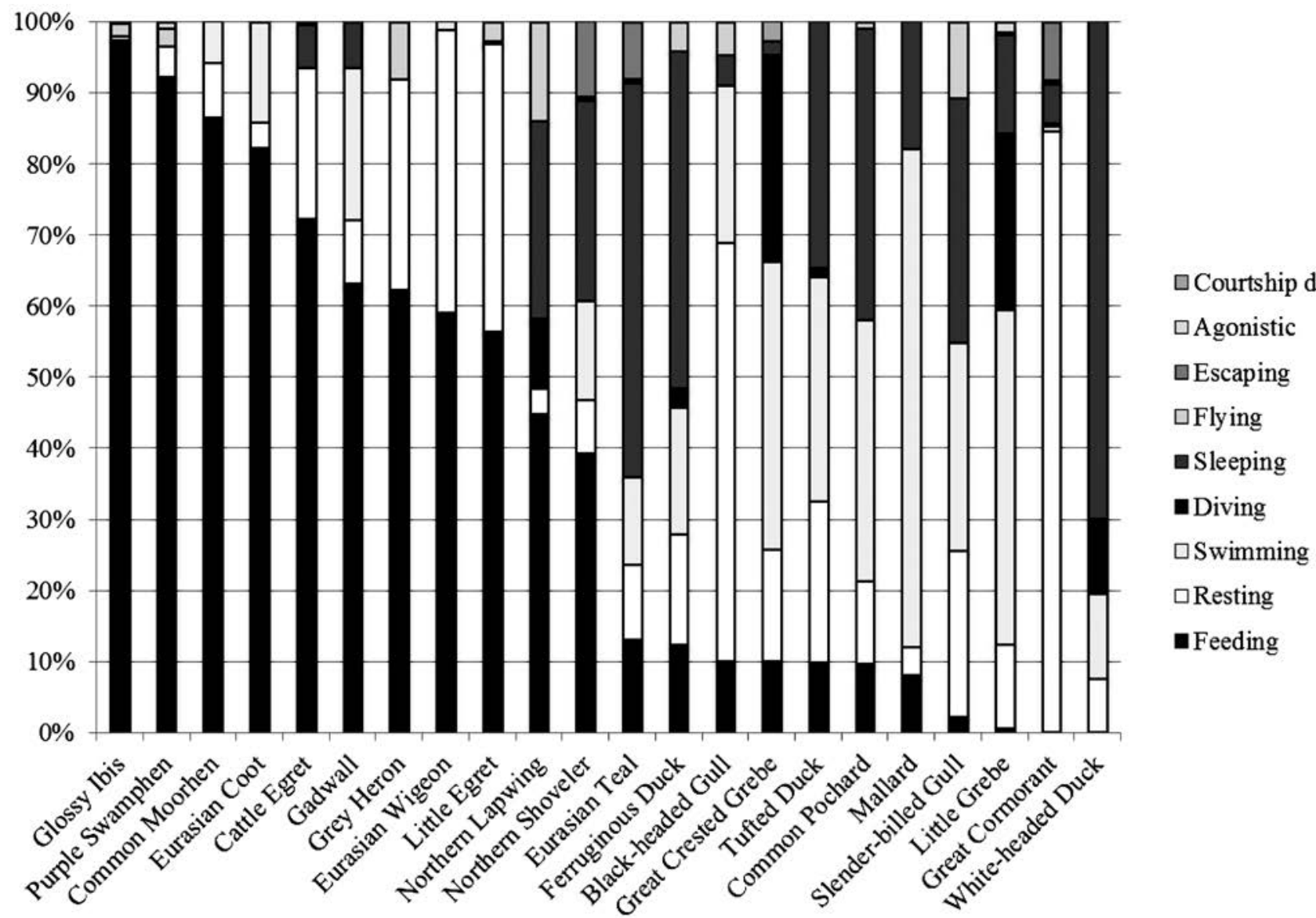

Fig. 2 - Proportional time budgets spent in activities by 22 species from September 2014 to February 2015 . (Values are given as a percentage of 108h).

The second group was formed by species restricted to sleeping behaviour where the proportion of time allocated for this activity was ranging from 40 to $75 \%$ (Figs. 2 and $3)$. Species in this group included White-headed Duck, Ferruginous Duck, Eurasian Teal Anas crecca, Common Pochard Aythya ferina, Slender-billed Gull Chroicocephalus genei and Tufted Duck Aythya fuligula.

The third group included the most dynamic species with high percentage of swimming activity (from 50 to 90\%) such as Little Grebe Tachybaptus ruficollis, Great Crested Grebe Podiceps cristatus and Mallard Anas platyrhynchos.

The last group was composed by species positively associated with high percentage of resting behaviour from 70 to $90 \%$ of their diurnal time (Figs. 2 and 3), such as Great Cormorant Phalacrocorax carbo and Black-headed Gull Chroicocephalus ridibundus.

Furthermore, we observed that the other activities (escaping, diving, flying, aggression and courtship display) were occasionally showed, i.e. all birds did not spend a lot of time or were never been observed in one of these behaviours. Also, desire of copulate, exhibited by courtship behaviours such as movements, vocalizations, or displays in this period of study was only restricted to Great Crested Grebe (7.45\% of the time budget) and Eurasian Coot (0.02\%) (Fig. 2).
The partitioning of the daytime between the main activities varied greatly among species (Fig. 4). Palearctic migrants spent much more time in sleeping ( $\chi 2$ without Yates' correction $=1188.07 ; \mathrm{df}=1 ; \mathrm{P}<0.001)$, swimming $\left(\chi^{2}\right.$ without Yates' correction $\left.=1413.4 ; \mathrm{df}=1 ; \mathrm{P}<0.001\right)$ and resting $\left(\chi^{2}\right.$ without Yates' correction $=341.5 ; \mathrm{df}=1$; $\mathrm{P}<0.001)$ when compared to resident species that spent their time mostly in feeding activity ( $\chi^{2}$ without Yates' correction=5476.09; $\mathrm{df}=1 ; \mathrm{P}<0.001)$.

\section{Activity rhythm}

There was no difference in the proportion of time spent on different activities at the course of daylight hours for resident species $\left(\chi^{2}\right.$ without Yates' correction $=3.32 ; \mathrm{df}=8$; $\mathrm{P}=0.9$ ). A basically uniform foraging rhythm was exhibited by this group of species. Also they rest, swim and slept uniformly during the two time periods of the day (Fig. $5)$. On the other hand, migrant species change their time budget throughout the daylight hours $\left(\chi^{2}\right.$ without Yates' correction $=20.9 ; \mathrm{df}=8 ; \mathrm{P}<0.001)$, birds in this assemblage fed and rest much more in the morning, in contrast they swim and spent much more time exploring underwater in the afternoon.

Observational results (Fig. 6) were only from the major diurnal activities observed, in late summer-early winter as 
Paired group (UPGMA) methode to aggregate data and the Bray-Curtis methode to calculate distences

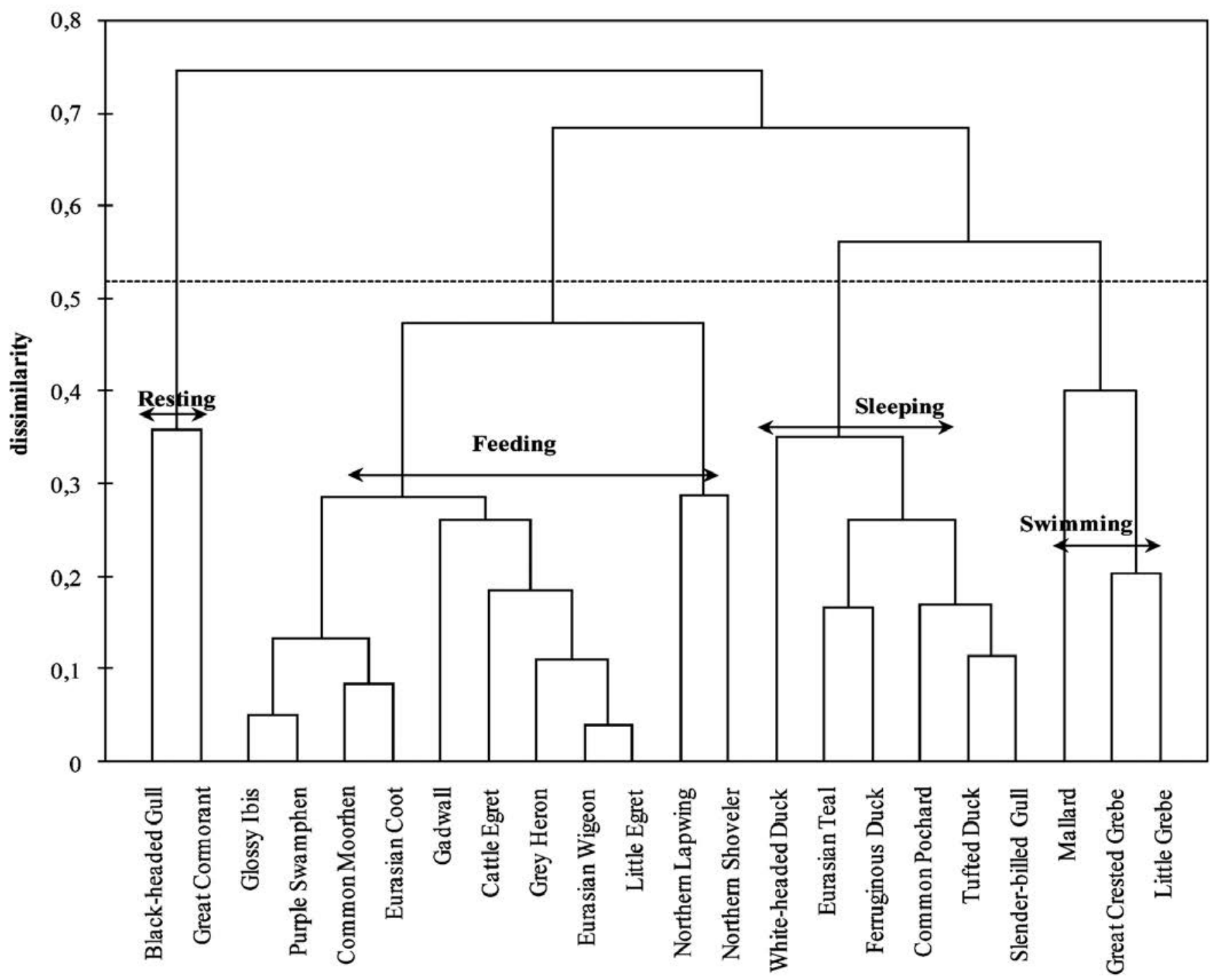

Fig. 3 - Hierarchical clustering using time budgets similarities among 22 waterbird species.

in late winter resident and migrant waterbirds did not behave similarly (early: $\chi^{2}$ without Yates' correction without Yates' correction $=72.91 ; \mathrm{df}=3 ; \mathrm{P}<0.001$; late: $\chi^{2}$ without Yates' correction $=22.08 ; \mathrm{df}=3 ; \mathrm{P}<0.001$ ), the first group spent much more time feeding as compared to the second group. Resident species behaved uniformly $\left(\chi^{2}\right.$ without Yates' correction $=1.53 ; \mathrm{df}=3 ; \mathrm{P}=0.67)$, in contrast, diurnal time budget of migrant birds varied during the studied period $\left(\chi^{2}\right.$ without Yates' correction $\left.=54.99 ; \mathrm{df}=3 ; \mathrm{P}<0.001\right)$ as they slept and swam much more in late summer-early winter but fed and rested mostly in late winter.

\section{DISCUSSION}

Our results suggest that all birds spent much more of their daytime in four major activities. Firstly, foraging and feeding behaviours were the most frequently occurring, probably due to the availability of several foraging habitat types and abundant food items during the wintering season. These species were clustered into two different guilds. The first guild, included shallow-water generalists and omnivorous species (two Rails: Eurasian Coot; Common Moorhen and three dabbling ducks: Gadwall; Northern Shoveler and Eurasian Wigeon) which mainly benefited from the high plant biomass in this eutrophic ecosystem. More than $90 \%$ of the observed individuals (Fig. 7) of these birds used open water body as a foraging habitat. These species still observed pecking and gathering emergent, submergent, or floating aquatic plants and furthermore trapping other food items on the surface of the water as they swam (the most used for feeding by this guild were Potamogetonaceae as Potamogeton lucens, Poaceae, Cyperaceae, Typhaceae and Haloragaceae as Myriophyllum verticillatum; Bakaria et al., 2002 and personal observations). This guild were also observed feeding with lower proportions (less than 3\% of total observation) (Fig. 7 ) in the lakeshore zones (Flooded meadows) where an open land vegetated with grasses, forbs and macrophytes 


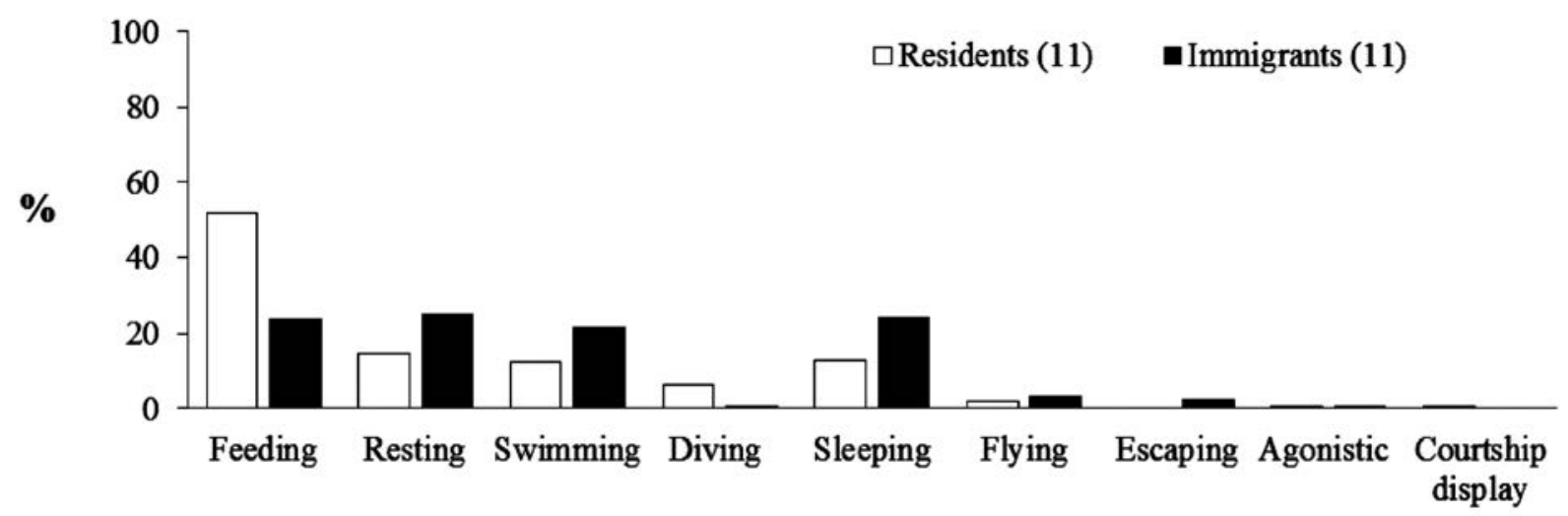

Fig. 4 - Total Proportional time budgets (mean) spent in activities among resident and immigrant birds during the study period. (Values are given as a percentage of $108 \mathrm{~h}$ ).

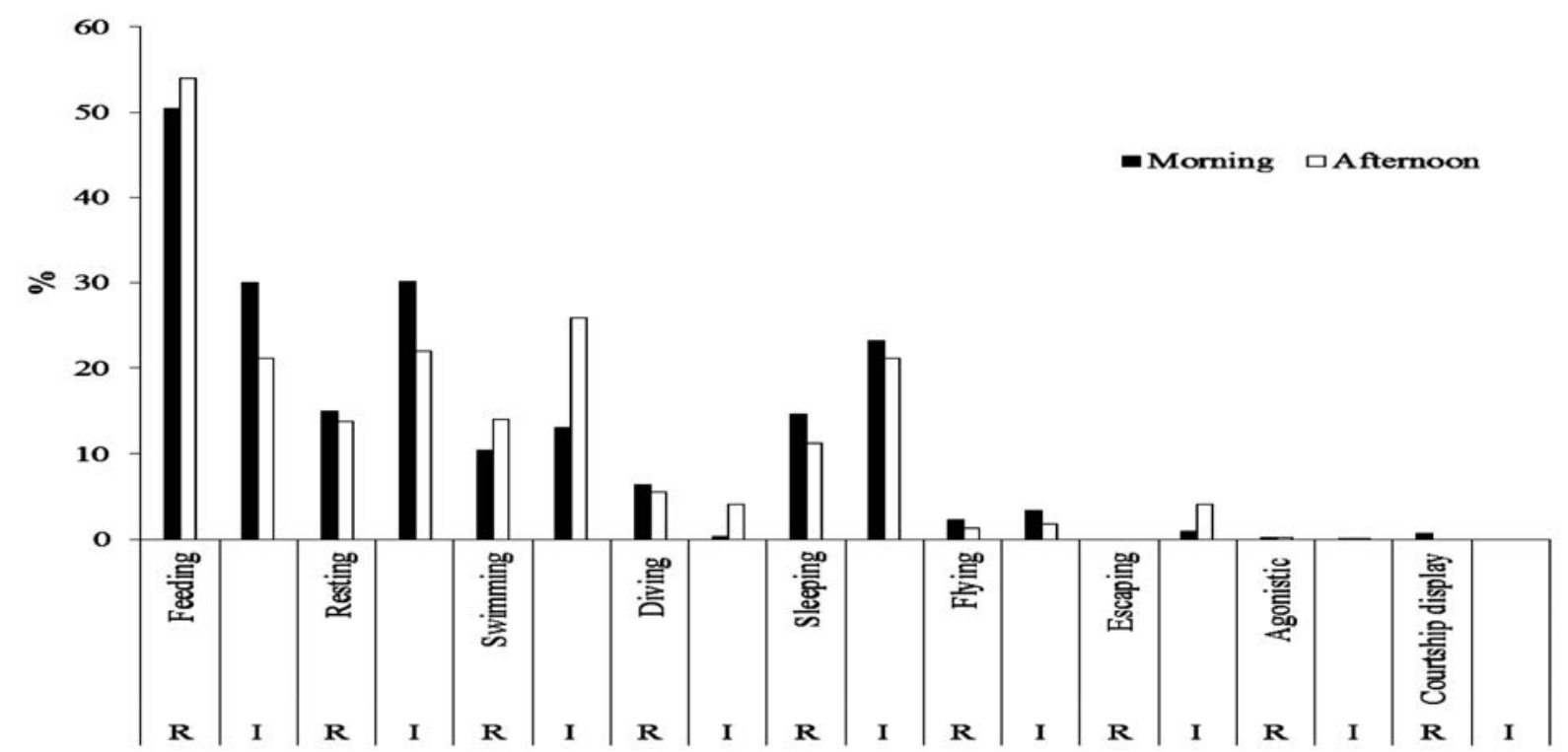

Fig. 5 - Proportional time budgets (mean) spent by resident and immigrant birds in activities among the diurnal time. (Percentage of $60 \mathrm{~h}$ in the morning and $40 \mathrm{~h}$ in the afternoon).

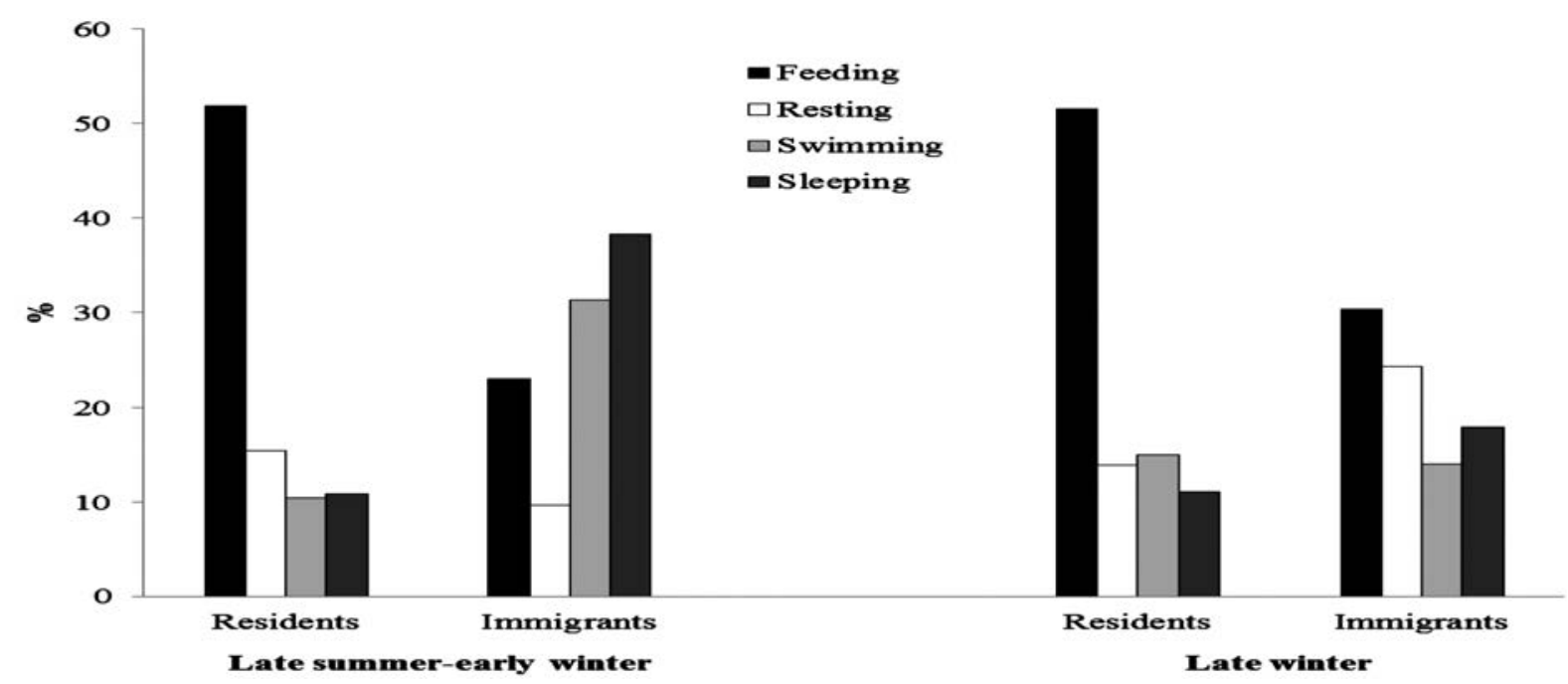

Fig. 6 - Relationship between status and time spent in feeding, sleeping, resting and swimming during the two sub-periods (proportion of $54 \mathrm{~h}$ both in late summer-early winter and late winter). 
as Phragmites australis; Typha angustifolia and Scirpus lacustris. The second guild consisted of three heron species: Little Egret, Cattle Egret and Grey Heron and 2 other long-legged wading birds as Purple Swamphen and Glossy Ibis. Both foraged in several habitats but in different proportions (Fig.7). Herons mainly used open water body $(31.25 \%)$ especially shallow waters [the average depth of the lake in some central points is $0.5 \mathrm{~m}$ (Raachi, 2007)] where they are frequently observed capturing prey by striking (personal observations), followed by uncultivated field $(26.56 \%)$ (Mainly used by Cattle Egret), and flooded meadows (24.21\%). Further, herons in this lake never observed foraging in mudflats $(0 \%)$. The latter result is much lower with Vasilios (2010) observations (18.8\%) in the Saronikos Gulf, western Attiki, Greece, this is could be due to differences in habitat features and levels of edges disturbances.

More than $1 / 2$ of the observed individuals of Purple Swamphen and Glossy Ibis used flooded meadows (Fig.
7) as a foraging habitat, followed by mud (34.13\%), these species often observed eating small invertebrates picked out of mudflat or exposed soil.

Waders and Grebes are a single-species guild that exclusively used a single foraging habitat (Fig. 7). Flooded meadows are the preferred habitat patches for waders with proportion of $92 \%$. Grebes fed exclusively through open water body, it never observed outside from this habitat category during the wintering period (Fig.7).

Secondly, sleeping is the main activity of four diving ducks, among them the endangered Ferruginous Duck and White-headed Duck. These birds sleep exclusively in the open water body (Fig.7), mainly offshore relatively far from the coastline of the lake, this is perhaps associated with the high level of sensitivity to disturbance of these species (Draidi et al., 2013; Meziane et al., 2014). Also, other groups were always observed sleeping in this category of habitat, except waders that sleep only in flooded meadows (Fig. 7).
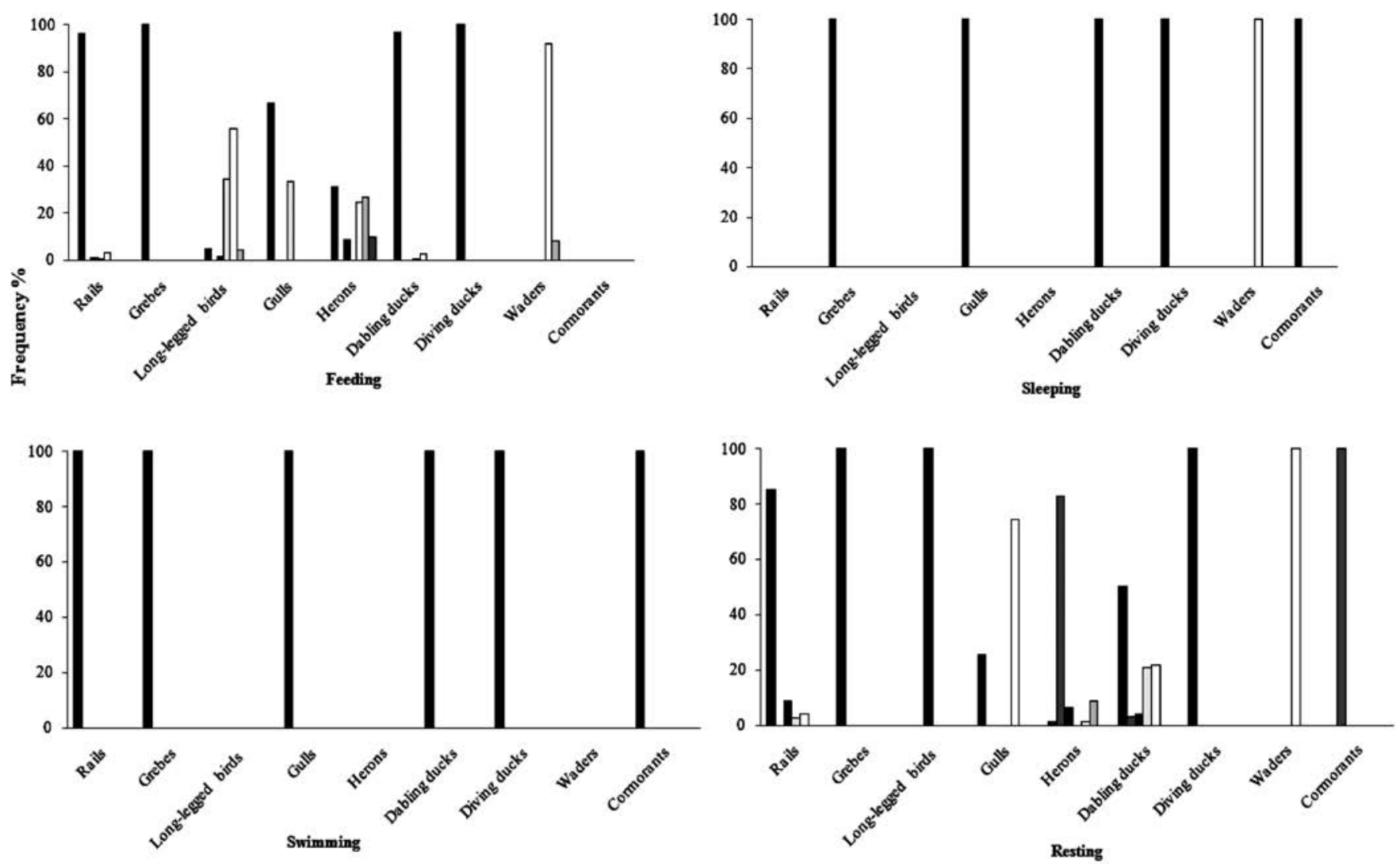

\begin{tabular}{|l|r|}
\hline Guild & Total observations \\
\hline Herons & 1694 \\
\hline long-legged wading birds & 882 \\
\hline Rails & 11965 \\
\hline Grebs & 3711 \\
\hline Gulls & 1683 \\
\hline Diving duck & 442 \\
\hline Dabbling duck & 12697 \\
\hline Waders & 554 \\
\hline cormorants & 882 \\
\hline
\end{tabular}



Fig.7 - Use of the seven habitat categories by multi-species assemblages. 
The $3^{\text {rd }}$ behaviour occurred (swimming) is the main activity of grebes which are the most active species in this Lake among winter. For these birds swimming is often used as behaviour to search food resources either under or on open water body (Fig. 7) (e.g. Ulenaers et al., 1992; Fox, 1994). The remained groups were exclusively observed swimming in this portion of the Lake (Fig. 7).

Finally, the wetland is considered as roosting area mainly by Cormorants and Herons since they spent most of their day time resting and preening especially in Floating-leafed vegetation which are small islets in the middle of the lake dominated by a very dense submerged and floating vascular plants, principally the White Water-lily Nymphaea alba (see also Lekuona, 2002). Diving ducks, Grebes, and Rails mainly rest in Open water body with high proportions $100 \%$ and $85 \%$ respectively (Fig. 7). Waders and Gulls preferred resting in flooded meadows with proportions of $75 \%$ and $100 \%$ respectively (Fig. 7). The Dabbling ducks species displayed an even higher diversity in the use of habitat categories in comfort activities principally, open water body $(50 \%)$, flooded meadows $(22 \%)$, mudflats $(21 \%)$, tall emergent vegetation $(4 \%)$, and floating-leafed vegetation (3\%).

Furthermore, flying, escaping and social interactions such as courtship and agonistic display occupied a minor part of the waterbirds' diurnal time. Generally, flight and escaping occurrences appear due to many factors of di- sturbance: i) natural, such as during flights of the marauding Marsh Harrier Circus aeruginosus, or the antagonistic behaviour among various individuals (intra-specific or inter-specific antagonism) and ii) anthropic disturbances, such as farming, fishing, building, and also illegal hunting (Aissaoui, 2009) The first breeders on the lake were Great Crested Grebe and Eurasian Coot (Rizi et al., 1999; Rouibi et al., 2013) and this may explains their courtship behaviours in late winter.

However, in our study we can only draw conclusions about daylight hours. Since habitat use can be very different at night (see Green, 1998), any time budgets based only on diurnal observations may be misleading (Fasola \& Canova, 1993).

Resident species, as Herons and Rails, were the most feeders and did not change their activity budgets either in daytime or around the study period. For these birds winter corresponds to their moulting period (all these species breed between spring and early summer in our study area: see Bakaria et al., 2002; Belhadj et al., 2007; Nedjah et al., 2010), therefore, due to the increased energetic demands and other physiological requirements (Döpfner, 2009), they spent more than half of their daytime feeding. Migrants, as dabbling and diving ducks and gulls fed less than residents: they spent the same proportion of time on the four major activities, previous research (e.g. Fasola \& Canova, 1993) indicates that wintering ducks

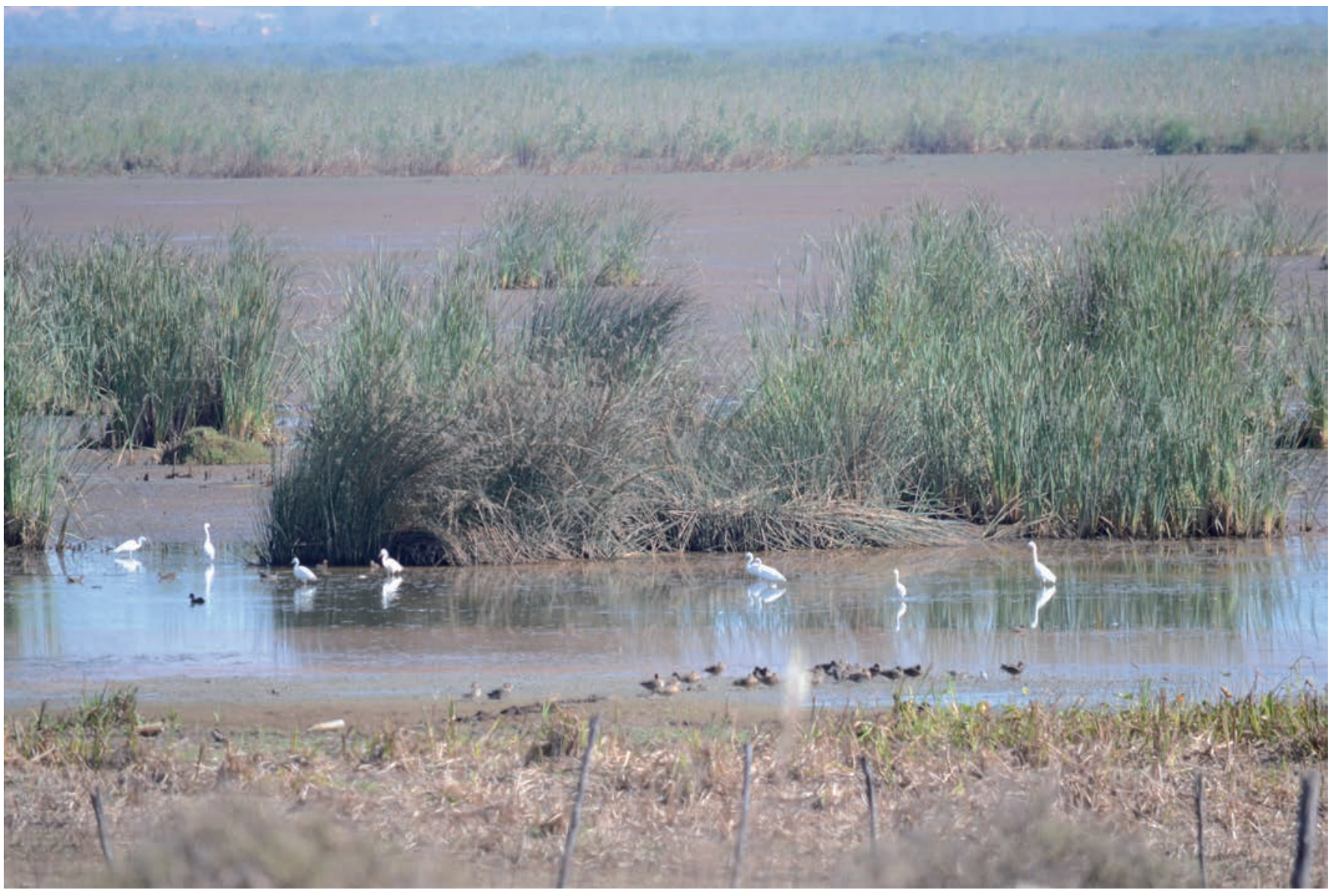

Fig. 8 - Little Egret and Gadwall benefits some wetland microhabitats in Lake Tonga. (Photo taken on 09/10/2014 by Elafri Ali). 
feed almost exclusively at night. Against resident species, activity schedules of migrant waterbirds were affected by seasonal periods: sleeping was the highest at early winter matching the migratory arrival dates; depending on the travelled distance birds spent more daytime sleeping than any other activities (Newton \& Brockie, 2008).

This natural Mediterranean wetland appears an important area for waterbird since it allows them to exercise all their main activities with limited natural or human-induced disturbances. It constitutes an important foraging site for most species (Herons, Rails, dabbling ducks and other wading birds). Moreover, Lake Tonga was an excellent roosting area of diurnal time-activity budgets (including sleeping and swimming) especially for colonial waterbirds (Cormorants and Gulls) and diving ducks, among them the endangered Ferruginous Duck and White-headed Duck.

The existing of numerous habitat types may favour the use of this natural wetland in a complementary way by a high number of waterbirds. A variety of foraging habitat types was used during the wintering season. Although interspecific variation in habitat use was considerable, the 3 main habitat types, open water body, mudflats, and flooded meadows were the most utilized by almost all species (Fig. 8). In contrast, floating-leafed vegetation, and tall emergent vegetation [Scirpus lacustris, Typha angustifolia, Nymphaea alba, Salix atrocinerea and Phragmites australis (Boumezbeur, 1993)], which accounted for $80 \%$ of the area, were mainly preferred in resting activities (Cormorants and Herons). In addition, other characteristics of this wetland as i) large size area (2700 ha) and ii) relative depth, iii) it is near to the sea and other several wetlands and iv) very difficult accessibility for human and predators offering a quietness refuge for the focalized species.

The acquired knowledge about the behaviour requirements of these waterbirds and describing the main related features of the landscape can be used for the conservation and proper management (Integrative management strategies can enhance conditions for waterbird guilds with different habitat requirements) of this and other coastal wetlands of the Mediterranean as well as similar areas around the world.

\section{Acknowledgments}

A special thank is given to Corrado Battisti, 'Torre Flavia' LTER (Long Term Ecological Reserach) Station, Città Metropolitana di Roma Capitale, Protected area Service, via Tiburtina, 691, 00159 Rome, Italy, for reviewing this manuscript and for his interesting comments. Also we would like to thanks Alessandro Zocchi, for reviewing the English language of this manuscript.

\section{REFERENCES}

Aissaoui R., Houhamdi M. \& Samraoui B., 2009 - EcoÉthologie des Fuligules Nyroca Aythya nyroca dans le Lac Tonga (Site Ramsar, Parc National d'El-Kala, Nord-Est de l'Algérie). European Journal of Scientific Research, 28: 47-59.
Altmann J., 1974 - Observational study of behavior: sampling methods. Behaviour, 49: 227-267.

Bakaria F., Rizi H., Ziane N., Chabi Y. \& Banbura J., $2002-$ Breeding ecology of whiskered terns (Chlidonias hybrid) in Algeria, North Africa. Waterbirds, 25 (1): 5662.

Belhadj G.H., Chalabi B., Chabi Y., Yves K. \& GauthierClerc M., 2007 - The breeding biology of the Cattle Egret Bubulcus ibis, the Little Egret Egretta garzetta, the Squacco Heron Ardeola ralloides, the BlackCrowned Night Heron Nycticorax nycticorax, the Purple Heron Ardea purpurea and the Glossy Ibis Plegadis falcinellus, at the Lac Tonga, Algeria. European Journal of Scientific Research, 19 (1): 58-70.

Boumezbeur A., 1993 - Ecologie et biologie de la reproduction de l'Erismature à tête blanche (Oxyura leucocephala) et du Fuligule nyroca (Aythya nyroca) sur le lac Tonga et le lac des oiseaux (Est algérien), (Mesures de protection et de gestion du lac Tonga). Doctorat, Université des hautes études Montpellier.

Chettibi F., Khelifa R., Aberkane M., Bouslama Z. \& Houhamdi M., 2013 - Diurnal activity budget and breeding ecology of the White-headed Duck Oxyura leucocephala at Lake Tonga (North-east Algeria). Zoology and Ecology. DOI: 10.1080/21658005.2013.817516.

Clark H.B. \& Montague Whiting R., 1994 - Time budgets of mallards and wood ducks wintering in a flooded bottomland hardwood forest. Proceedings of the Southeastern Association of Fish and Wildlife Agencies, 48: 22-30.

Döpfner M., Quillfeldt P. \& Bauer HG., 2009 - Changes in behavioral time allocation of waterbirds in wingmolt at Lake Constance. Waterbirds, 32 (4): 559-571.

Draidi K., Bakhouche B., Telailia S., Houhamdi M. \& Bouslama Z., 2013 - Le Fuligule nyroca Aythya nyroca dans le Lac Tonga (Nord Est de l'Algérie): Dénombrement et étude des rythmes d'activités diurnes. European Journal of Scientific Research, 102 (3): 333-342.

Elafri A., Halassi I. \& Houhamdi M., 2016 - Diversity patterns and seasonal variation of the waterbird community in mediterranean wetlands of Northeastern Algeria. Zoology and Ecology, 26 (2): 85-92. DOI: 10.1080/21658005.2016.1163865

Fasola M. \& Canova L., 1993 - Diet activity of resident and immigrant waterbirds at Lake Turkana, Kenya. Ibis, 135: 442-450.

Fox A.D., 1994 - Estuarine winter feeding patterns of Little Grebes Tachybaptus ruficollis in central Wales. Bird Study, 41: 15-24.

Green A.J., 1998 - Habitat selection by the Marbled Teal Marmaronetta angustirostris, Ferruginous Duck Aythya nyroca and other ducks in the Goksu Delta, Turkey, in summer. Revue d'Ecologie (Terre Vie), 53: 225-243.

Green A.J. \& El Hamzaoui M., 2000 - Diurnal behaviour and habitat use of non breeding Marbled Teal, Marmaronetta angustirostris. Canadian Journal of Zoology, 78: 2112-2118.

Green A.J., 1998 - Comparative feeding behaviour and niche organization in a Mediterranean duck community. Canadian Journal of Zoology, 76: 500-507. 
Hepworth G. \& Hamilton JA., 2001 - Scan sampling and waterfowl activity budget studies: Design and analysis considerations. Behaviour, 138: 1391-1405.

Hoffmann L., Hafner H. \& Salathé T., 1996 - The contribution of colonial waterbird research to wetland conservation in the Mediterranean region. Colonial Waterbirds, 19: 12-30.

Houhamdi M. \& Samraoui B., 2001 - Diurnal time budget of wintering Teal Anas crecca at Lac des Oiseaux, northeast Algeria. Wildfowl, 52: 87-96.

Kloskowski J., Green A.J., Polak M., Bustamante J. \& Krogulec J., 2009 - Complementary use of natural and artificial wetlands by waterbirds wintering in Doňana, south-west Spain. Aquatic Conservation Marine and Freshwater Ecosystem, 19: 815-826.

Lazli A., Boumezbeur A., Moali-Grine N. \& Moali A., 2011 - Évolution de la population nicheuse de l'Erismature à tête blanche Oxyura leucocephala sur le lac Tonga (Algérie). Revue d'Ecologie (Terre Vie), 66: 173-181.

Lazli A., Boumezbeur A., \& Moali A., 2012 - Statut et phénologie de la reproduction du fuligule nyroca Aythya nyroca au lac Tonga (nord-est algérien). Alauda, 80 (3): 219-228.

Lekuona J.M., 2002 - Food intake, feeding behaviour and stock losses of cormorants, Phalacrocorax carbo, and grey herons, Ardea cinerea, at a fish farm in Arcachon Bay (Southwest France) during breeding and non-breeding season. Folia Zoologica, 51 (1): 23-34.

Liordos V., 2010 - Foraging guilds of waterbirds wintering in a Mediterranean coastal wetland. Zoological Studies, 49 (3): 311-323.

Magurran A., 2004 - Measuring biological diversity. Blackwell Publishing.

Meziane N., Samraoui F. \& Samraoui B., 2014 - Status and diurnal activity budget of non-breeding Whiteheaded Ducks Oxyura leucocephala in Algeria. Ostrich, 85 (2): 177-183.

Nedjah R., Boucheker A., Samraoui F., Menaï R., Alfarhan A., Al-Rasheid K. \& Samraoui B., 2010 Breeding ecology of the Purple Heron Ardea purpurea in Numidia, north-eastern Algeria. Ostrich, 81 (3): 189-196.

Newton I. \& Brockie K., 2008 - The migration ecology of birds. Academic Press.

Paracuellos M., 2006 - How can habitat selection affect the use of a wetland complex by waterbirds? Biodiversity and Conservation, 15: 4569-4582.

Raachi M.L., 2007 - Étude préalable pour une gestion intégrée des ressources du bassin versant du Lac Tonga au Nord-est Algérien. Mémoire présenté comme exigence partielle de la maîtrise en géographie. Université du Québec à Montréal.

Rajpar M.N. \& Zakaria M., 2011 - Bird species abundance and their correlationship with microclimate and habitat variables at Natural Wetland Reserve, Peninsular Malaysia. International Journal of Zoology. DOI: $10.1155 / 2011 / 758573$

Rizi H., Benyacoub S., Chabi Y. \& Banbura J., 1999 Nesting and reproductive characteristics of Coots
Fulica atra breeding on two lakes in Algeria. Ardeola, 46 (2): 179-186.

Rouibi A., Zitouni A., Tahar A. \& Houhamdi M., 2013 Breeding ecology of the Great crested grebe (Podiceps cristatus) in Tonga Lake (Northeast Algeria). European Journal of Scientific Research, 100 (3): 534-541.

Samraoui F., Alfarhan A. \& Samraoui B., 2013 - Status and breeding ecology of the Common Moorhen Gallinula chloropus in Algeria. Ostrich, 84 (2): 137 144.

Samraoui B. \& Samraoui F., 2008 - An ornithological survey of the wetlands of Algeria: Important Bird Areas, Ramsar sites and threatened species. Wildfowl, 58: 71-98.

Samraoui F., Alfarhan A.H., Al-Rasheid Khaled A.S. \& Samraoui B., 2011 - An appraisal of the status and distribution of waterbirds of Algeria: Indicators of global changes? Ardeola, 58 (1): 137-163.

Scarton F., Bon M., Perco F. \& Verza E., 2013 - Wintering waterbirds along coastal wetlands of FriuliVenezia Giulia and Veneto (1997-2006). Rivista italiana di Ornitologia, 82 (1-2): 94-99. DOI: 10.4081/ rio. 2012.119

Shine C. \& De Klemm C., 1999 - Wetlands, water and law: using law to advance wetland conservation and wise use. IUCN Environmental Policy and Law Paper, 38

Thompson J.D. \& Baldassarre G.A., 1991 - Activity patterns of nearctic dabbling ducks wintering in Yucatan, Mexico. The Auk, 108 (4): 934-941.

Ulenaers P., Van Vessem J. \& Dhondt A.A., 1992 - Foraging of the Great Crested Grebe in relation to food supply. Journal of Animal Ecology, 61: 659-667.

Vasilios L., 2010 - Foraging guilds of waterbirds wintering in a Mediterranean coastal wetland. Zoological Studies, 49 (3): 311-323. 